\title{
Detecting fraud in Chinese listed company balance sheets
}

\author{
Yi Wei, Jianguo Chen, Carolyn Wirth
}

School of Economics and Finance, Massey University, Palmerston North, New Zealand

\begin{abstract}
Purpose - This study investigates the links between accounting values in Chinese listed companies' balance sheets and the exposure of their fraudulent activities.

Design/methodology/approach-Every balance sheet account is proposed to be a potential vehicle to manipulate financial statements.

Findings-Other receivables, inventories, prepaid expenses, employee benefits payables and long-term payables are important indicators of fraudulent financial statements. These results confirm that asset account manipulation is frequently carried out and cast doubt on earlier conclusions by researchers that inflation of liabilities is the most common source of financial statement manipulation.

Originality/value - Prior practices of solely scaling balance sheet values by assets are revealed to produce spurious relationships, while scaling by both assets and sales effectively detects fraudulent financial statements and provides a useful fraud prediction tool for Chinese auditors, regulators and investors.
\end{abstract}

Keywords Fraudulent statements, Accounting ratios, China Paper type Research paper 


\section{Introduction}

This study investigates the role of accounting balance sheet values in detecting fraudulent financial statements (FFS). Weak capital market regulatory oversight and a lack of transparency in corporate governance and financial reporting practices foster opportunities for earnings management in the Chinese market. The need for managers to exercise subjective judgement in financial reporting allows for earnings management opportunities that can lead to stock mispricing and the extraction of private benefits. Hence, the distinct features of the Chinese financial system provide opportunities for controlling shareholders and managers of listed firms to engage in fraudulent activities (Baucus and Near, 1991). This has resulted in the recent exposure of many cases of fraud (Jia et al., 2009). For example, 581 enforcement actions were taken against listed firms between 1994 and 2007 (Chen et al., 2006). The contribution of this study is to forecast the incidence of fraud in Chinese listed firms by examining balance sheet accounts.

The China Securities Regulatory Commission (CSRC) is the main regulator of securities markets in China. The CSRC conducts regular as well as random reviews of listed companies, investigates cases of fraud, and carries out enforcement actions (Chen et al., 2006). However, their exposure of fraudulent activities tends to be superficial and lacks timeliness. For example, in 2005 the Koyo Group was punished by both the Shenzhen Stock Exchange (SZSE) and the CSRC for concealing significant information, including a large amount of lending, illegal diversion of funds to controlling shareholders, and the true ownership of the firm. Such cases raise questions for investors. For example, how did the Koyo Group manage to hide substantial economic transactions in its account balances? In 2007, two years after the CSRC's exposure of fraud, the details were finally made public. The Koyo Group fabricated a series of 'bank statements' and falsified 'prepaid expenses for in-progress projects', thereby concealing 1.4 billion RMB in losses from three high-tech projects. From 2000 to 2003, they also inflated construction in-progress, other receivables, biochemical construction, fixed assets and management fees by a total of 169 million RMB. Yet, from the scant information announced by the CSRC in 2005, it was difficult for market participants to identify the true extent of the firm's financial manipulation. Many studies have successfully detected FFS, but they have tended to focus on the role of corporate governance, in both China and developed countries (Agrawal and Chadha, 2005; Chen and Yuan, 2004; Jian and Wong, 2010; Liu and 
Lu, 2007). This study extends this literature by identifying special relationships between balance sheet accounts of Chinese listed firms to more timely detect the incidence of FFS.

Several contributions to the literature are made. First, every account in the balance sheet is considered as a potential vehicle for identifying FFS. Using a hand-collected database of CSRC enforcement actions for fraudulent activities by Chinese listed companies, specific balance sheet accounts are identified that predict each different type of financial statement violation. Through robustness tests, these relationships continue to hold. The intuition is as follows. In contrast to practices in developed countries, top Chinese managers frequently possess total control over the accounting system (Luo and Hassan, 2009). As a result, management can hide fraudulent behaviour in the accounts with less chance of being discovered.

Second, the results are substantiated by scaling the probit regression variables using both assets and sales in order to model the multivariate relationships with fraud. Evidence is presented of a link between balance sheet accounting values and subsequent detection of FFS by the CSRC. Fraudulent Chinese firms are found to frequently manipulate "other receivables", which is consistent with previous findings (Jiang et al., 2010). However, prior studies have tended to neglect to examine accounts such as other current assets and intangible assets, which are also unusually high in the sample of fraudulent Chinese firms.

Third, evidence is produced that past findings of higher leverage for fraudulent firms may result from a spurious relationship between leverage and FFS due to scaling account values by assets. Higher leverage may simply be the result of lower equity in fraudulent firms. Scaling by sales and studying the components of debt separately reveals evidence of lower leverage in some liability accounts of fraudulent firms.

Fourth, certain balance sheet accounts are found to be associated with different types of fraud violation. For example, frauds involving related-party transactions are associated with high "other receivables", "prepaid expense", "other currents", “short-term loans", “employee benefits payable", "long-term debt" and "long-term payables". The pattern of accounts identified allows for the effective prediction of each different type of fraud.

The usefulness of the developed probit model as a classification tool is also assessed. Correct predictions of fraudulent firms and non-fraudulent firms are above $56 \%$ for in-sample tests, 
and above $50 \%$ for some subsamples in out-of-sample tests. Applying the model to the population of all listed Chinese firms, the correct prediction of non-fraudulent firms is above $80 \%$. Thus, the evidence supports the helpfulness of balance sheet information in identifying FFS.

Finally, the hand-collection of a database of CSRC enforcement actions allows further insights into the relationship between corporate governance in Chinese market and the incidence of corporate fraud. Chinese market is characterised by a high concentration of state ownership; extremely low share ownership by insider managers and directors; a two-tier internal governance structure; a weak legal structure; deficient market control mechanisms; a lack of enforcement law; and an inefficient managerial labour market (Jiang et al., 2010). Evidence is produced that corporate governance is inadequate in preventing fraudulent behaviour.

The remainder of this paper proceeds as follows. Section 2 reviews the literature on fraudseeking activities and related theories. Section 3 describes the sample, data, and methods used in the study. Section 4 presents the empirical results and robustness checks are discussed in Section 5. Section 6 summaries the conclusions.

\section{Literature Review and Hypothesis development}

Instances of FFS have been prevalent in recent decades (e.g. Enron, WorldCom, Qwest) and auditors are increasingly under pressure to identify potential fraud. The challenge for researchers is how to detect fraud in a timely manner to minimize the loss of shareholders' funds. To date, the most frequently occurring fraudulent behaviours identified in balance sheets have been overstatements of income (or assets) or understatements of expenses (or liabilities) (Bonner et al., 1998; Spathis et al., 2002). Fraudulent statements often overstate revenue before it is earned, overstate assets by understating allowances for receivables, or overstate the value of inventory, property, and other tangible assets (Spathis et al., 2002). Beneish (1999a) finds three main techniques for manipulating profits are changing accounting methods, counterfeiting financial records, and prematurely or fictitiously recording expenses and revenues. 
Previous empirical findings identify certain asset-related financial statement variables that are often manipulated by firms under investigation for fraud. These accounts include accounts receivable (Bonner et al., 1998), other receivables (Jiang et al., 2010) and allowance for doubtful accounts and inventory (Stice, 1991). Simunic (1980) argues that auditing both receivables and inventories are complex tasks for auditors. These accounts require a forecast of future events, and are regarded as risky balance sheet components. Stice (1991) shows that there is generally a higher risk of error in an account when its value is derived from subjective judgement. When such accounts represent a relatively large portion of total assets, the prevalence of FFS increases.

Debt accounts have also been found to be common indicators of FFS. Chen et al. (2006) reveal that fraudulent firms have greater financial leverage than matched firms. Firms with higher leverage are more likely to violate debt covenants and less likely to gain additional capital (Fan et al., 2008). Therefore, managers have incentives to manipulate accounts by understating liabilities or overstating assets in order to meet certain debt covenants. When liabilities increase, the risk to equity owners and managers can be transferred to debt holders and the likelihood of FFS is increased (Spathis et al., 2002).

The above findings are generally consistent with managers' incentives to understate expenses or overstate revenues when a firm's profit is low. Beneish (1999a) finds that fraudulent firms have lower return on assets and higher sales growth than matched firms before public disclosure. Using a variety of profitability measures, Spathis et al. (2002) also find that fraudulent firms are less profitable than matched firms. Hence, the association between FFS and lower profitability suggests that managers may have incentives to manipulate accounting records in order to increase apparent firm profits.

Most earlier studies focus on specific types of violations and limit their hypotheses to the manipulation of certain accounts. In contrast, this study involves a systematic examination that covers all the accounts in the balance sheet. Using this method, this study seeks to answer two important questions. First, which balance sheet variables are most frequently used to engage in FFS? Second, which particular balance sheet variables are used to perpetuate each type of fraud? 
Double entry accounting rules imply that for firms with FFS, there will be higher asset account balances or lower liability account balances associated with a manipulated profit change. Accordingly, this study proposes the following hypothesis:

H1. Individual balance sheet account values for firms with FFS will be different from those in a matched sample of firms without FFS.

In contrast to the previous literature, this study proposes that fraudulent manipulation of financial statements could arise in many different accounts with different companies and for different motivations. For example, in 1996 Qiongminyuan recorded fictitious profits of 540 million RMB and inflated the capital reserve by 6.57 billion RMB. Also in 1996, Chengdu Hongguang recorded a fictitious profit of 157 million RMB by fabricating sales, inflating inventory and manipulating other accounts. Hence, for different types of fraud, firms are motivated by different incentives; some relate to the firm's rights issuance (Chen and Yuan, 2004) and others relate to the managers' personal interests. For example, Jian and Wong (2010) find that subsequent to propping up failing firms, controlling shareholders tunnel cash for their personal benefit by creating fictitious related party loans receivable.

Following from the above, this study proposes that there are systematic relationships between the type of fraudulent behaviour and the choice of balance sheet account used. Hence, different types of fraud violation will be associated with different balance sheet accounts. This leads to the second hypothesis:

H2. There exists a relationship between the type of fraud violation undertaken and the specific balance sheet accounts manipulated.

If different accounts are used for different types of fraud, then a comprehensive testing method is necessary. Earlier studies tend to focus on certain account ratios to find possible indicators of fraud (Chen et al., 2006; Jiang et al., 2010). Yet, restricting the analysis in this way may cause a missing variable problem in the regression equation. This study undertakes a more comprehensive approach to distinguish between fraudulent and non-fraudulent financial statements by including all balance sheet accounts as explanatory variables to avoid the missing variable bias. This is particularly important for Chinese firms because of the special features of corporate governance in China. Regulatory pressures create certain financial restrictions for Chinese firms and this may stimulate fraudulent behaviour, such as 
smoothing earnings to improve financial performance, recover lost reputational capital or gain additional sources of funds (Szwajkowski, 1985). Chinese financial disclosure lacks transparency (Liu, 2006), and this provides the opportunity for deception by managing earnings (Aharony et al., 2000). If managers are trying to deceive auditors and investors, they will choose to falsify those accounts that are most easily manipulated and/or have less chance of being detected. Therefore, it is important to investigate all balance sheet accounts.

\section{Sample and Methodology}

The sample comprises 656 unique cases of FFS by 313 listed Chinese firms (hereafter, fraudulent firms), reported between 1994 and 2011. This study also classifies the sample into two subsamples. The first subsample includes FFS cases of firms with either one violation announcement or multiple violation announcements from non-consecutive years. The second subsample consists of FFS cases of firms with multiple violation announcements from consecutive years. The likelihood of detection of fraud by the CSRC is expected to be greater for firms found to commit numerous violations over consecutive years. For data analysis purposes, the "announcement year" is defined as the first year in which fraudulent reporting is exposed.

The majority of the violations data are hand-collected from the descriptive information in Punishment Bulletins issued by the CSRC and the Integrity of Files websites maintained by the SHSE and SZSE. In addition, some cases of FFS are collected from the Law Yearbook of China, Securities Times, Shanghai Securities Daily and yearbooks produced by the two stock exchanges. For some firms, fraudulent reporting is disclosed twice or more. For example, three violations are reported for Hunan Henyang Jinli Technology, which are treated as one firm and three FFS cases.

Prior to exclusions, a total of 734 cases of fraud are identified across 369 firms (see Panel A of Table 1). Firms for which annual report information is missing, that issue B-shares or are in the financial sector are excluded from the sample. Following Beasley (1996), each fraudulent firm is matched with a non-fraudulent firm. Matched firms must be in the same industry and of similar listing age and firm size (within 20 percent of the total assets of the related fraudulent firm) at the date of the fraudulent firm's exposure. To be included in the 
matching firm sample, financial statement data must be available for three years from one year prior to the fraud to one year after. For a firm that commits fraud in consecutive years, only one matched firm is chosen, based on the first fraud exposure. The sample firms' financial data are obtained from the China Stock Market and Accounting Research (CSMAR) financial database. The above procedure yields a sample of 656 cases across 313 fraudulent firms.

Table 1 also presents the sample distributions by year (Panel B), industry (Panel C) and violation type (Panel D) pertaining to exposed Chinese corporate fraudulent activities. Panel B reveals that the number of fraud cases increased dramatically between 2001 and 2011, having peaked in 2005. The pervasiveness of fraud is particularly evident when reviewed relative to all listed Chinese firms, peaking at 5.34\% in 2001. Panel C reveals that the sectors with the highest proportions of firm violations are manufacturing with $55.27 \%$ and real estate with $11.82 \%$.

The violation types that describe the nature of the offences are used to identify the linkages between balance sheet account values and the exposure of fraud. The violation types are listed in Panel D of Table 1 in descending order of frequency, and examples are provided in Appendix 1. Many fraud announcements report multiple violations, so in total there are 1143 instances of violations among the 656 cases.

\section{[Insert Table 1 Here]}

This study hypothesizes that fraudulent firms can potentially manipulate any balance sheet account to accomplish their deception. Accordingly, to detect fraudulent firms from information contained in their balance sheets, this study takes the novel approach of including all balance sheet accounts as explanatory variables in the analysis. This is in contrast to previous studies, which select fewer balance sheet account variables. The balance sheet accounts of fraudulent firms are expected to display some statistical differences relative to those of the matched firms.

Probit regression is employed to identify the relationships between accounting values and fraudulent behaviours in balance sheets. The identified model is then used in an out-ofsample period to predict firms likely to commit fraud in the future. In the probit regression, the dependent variable is the probability of fraud for firm $i$ and the main independent 
variables of interest are balance sheet account values, $\Sigma \mathrm{X}_{\mathrm{i}, \mathrm{j}, \mathrm{t}}$. Control variables are incorporated for the potential influence of corporate governance $\left(\Sigma \operatorname{control}_{\mathrm{i}, \mathrm{k}, \mathrm{t}}\right)$.

\section{Probit Model:}

Probability of $\left(\operatorname{Fraud}_{\mathrm{i}, \mathrm{t}}=1\right)=F\left(\alpha+\sum_{j=1}^{n} \beta_{j} X_{i, j, t}+\sum_{k=1}^{k} \beta_{k} \operatorname{control}_{i, k, t}\right)$

Where

$\mathrm{F}$ is the standard normal cumulative distribution function $(\mathrm{CDF})$; Fraud $=$ a dummy variable with a value of one when the firm is subject to an enforcement action and zero if it is a nonfraudulent matched firm;

$\Sigma \mathrm{X}_{\mathrm{i}, \mathrm{t}}=$ the explanatory variables of balance sheet account ratios;

In order to check the accuracy of the model, the following two measures are applied using insample and out-of-sample data:

1) Fraud prediction ratio (r1): the ratio of the number of correctly predicted fraudulent firms to the total number of fraudulent firms.

2) Non-fraud prediction ratio (r0): the ratio of the number of correctly predicted non-fraudulent firms relative to the total number of non-fraudulent firms.

A ratio result of 50\% implies a naïve prediction suggesting no predictive power for the model. Only when these ratios are above $50 \%$ can it be concluded that the model of balance sheet accounting variables is helpful in predicting FFS.

Prior studies show that the quality of corporate governance influences earnings quality and managerial manipulation (Beasley et al.; 1996; Chen et al., 2006; Liu and Lu, 2007). Accordingly, three groups of corporate governance variables pertaining to ownership structure, board of directors and other firm-level attributes are included as control variables in the above probit model. 


\section{Empirical results}

Table 2 compares the mean values of each balance sheet account scaled by total assets for fraudulent firms and matching firms.

\section{[Insert Table 2 Here]}

Reviewing the full sample results in Panel A of Table 2, many significant differences are observed between the fraudulent and matched samples. Among the asset accounts and relative to the matching firms, fraudulent firms have higher other receivables, other current accounts and intangible assets, but lower cash and cash equivalents, inventories and accounts receivable. For the liability and equity accounts, fraudulent firms have higher short-term loans, other short-term liabilities, other non-current liabilities, share capital and capital reserves, but lower other stockholders' equity.

Panels $\mathrm{B}$ and $\mathrm{C}$ of Table 2 present the respective mean balance sheet accounts for the nonconsecutive and consecutive subsamples. The direction of the results, the differences between the fraudulent and matching firms and the levels of significance are similar to the full sample results in Panel A. The differences between fraudulent and matched firms are greater for consecutive announcements, possibly due to their stronger pattern of on-going violations relative to non-consecutive announcements. For example, for cash and cash equivalents, the difference between fraudulent and matched firms is $6.1 \%$ for the consecutive subsample (Panel C), and only $2.6 \%$ for the non-consecutive subsample (Panel B).

Before undertaking the multivariate analysis, the possible influence of multicollinearity between the account variables must be addressed. In untabulated analyses, fixed assets and retained earnings are found to be correlated with the remaining variables. Accordingly, two OLS regressions are run, first with fixed assets and then with retained earnings as the dependent variable. The remaining balance sheet accounts are the explanatory variables. The residuals from these regressions are then substituted in place of the original values of fixed assets and retained earnings in subsequent analyses. By using the residuals collinearity has been effectively removed, but the identification problem has not been entirely solved. Hence, some of the relationships depicted in the other variables could possibly be due to the correlated fixed assets or retained earnings. Nevertheless, there is no difference between using the original values or the residuals, since the R-squared is the same in both regressions. 
After the above treatment for collinearity, probit regressions are used to test the relationships between balance sheet account values and the incidence of FFS, the results of which are shown in Table 3. Panels A to $\mathrm{C}$ of Table 3 provide in-sample results for the full, nonconsecutive and consecutive subsamples, respectively; Panels D to E report out-of-sample results separately. For the in-sample tests, data from all 1994 to 2011 time periods are used and for the out-of-sample tests the entire period is divided into two: the estimation period (first twelve years) and the prediction period (last six years). As expected, in Panels A to C of Table 3 consistently strong signals are observed in many variables. The consistently significant positive coefficients for other receivables, prepaid expenses and intangible assets, and negative coefficients for inventories indicate that enforcement action for FFS is more likely when firms report higher balances in the above asset accounts, and lower inventory balances. Most of the differences in the coefficients for these accounts in the subsample of consecutive firm announcements are more than double those of non-consecutive firms. On the liability side, the coefficients reported in the consecutive subsample for the variables short-term loans, employee benefits payable and long-term payables are more than triple those of the non-consecutive subsample, indicating even more extreme differences between firms that have and have not experienced enforcement actions for fraud. Furthermore, taxes payable and other non-current liabilities have coefficients that are significantly negative for the non-consecutive subsample but significantly positive for the consecutive subsample. The deferred tax liabilities account is strongly significant and positive for the non-consecutive subsample but negative and weakly significant within the consecutive subsample. On the equity side, the only variable of note is other stockholders' equity; the consecutive subsamples' coefficients are strongly significantly positive while the non-consecutive subsamples' coefficients are strongly significantly negative. These findings suggest that firms that are subject to enforcement actions may falsify particular accounts, or that they share certain problems that are reflected in their financial statements.

Generally the probit model results consistently support Hypothesis 1 that some balance sheet account values are different for fraudulent firms relative to a matched control sample of nonfraudulent firms. These ratios could potentially be used as indicators to detect fraudulent behaviour. Moreover, the signals of the presence of FFS are systematically stronger for firms with consecutive fraud announcements than for those with non-consecutive announcements. The most important signals on the asset side are the presence of higher other receivables, higher prepaid expenses, and lower inventories, and on the liability side are the incidence of 
higher short-term loans, employee benefits payable, and long-term payables. The finding of higher other receivable balances in firms targeted for enforcement action is consistent with previous findings (Jiang et al., 2010; Liu and Lu, 2007). However, the finding that fraudulent firms have lower inventory balances runs counter to prior research evidence from developed countries (Spathis et al., 2002). One possibility is that Chinese fraudulent firms may manipulate inventories downwards by selling goods to related parties in order to tunnel funds (Cheung et al., 2009; Peng et al., 2011). On the liability side, previous research presents evidence of higher leverage associated with fraudulent firms (Chen et al., 2006). A similar result is also found in this paper; however, by separating leverage into different accounts, lower liabilities are found in some accounts. One explanation is that the component accounts are subject to different degrees of managerial discretion. For example, employee benefits payable and long-term payables are 'soft' accounts that allow managers to exercise more subjective judgement in determining values relative to long-term debt (Dechow et al., 2011). Therefore, manipulators are more likely to misrepresent the former accounts.

Table 3 provides information on the model's predictive accuracy. The in-sample correct prediction rates are all greater than 50\%; however the accuracy for the stronger cases of consecutive announcements is greater than $80 \%$. A better test of predictability is achieved through out-of-sample tests, the results of which are shown in Panels D, E and F of Table 3. The model is based solely on data from the earlier estimation period (first twelve years) and the correct prediction rates are calculated using the balance sheet values from the later prediction period (last six years). Panels D, E and F indicate that the prediction accuracy of non-fraudulent firms is well above a naïve $50 \%$ benchmark, ranging from $82 \%$ for the nonconsecutive announcement subsample to $94 \%$ for the consecutive announcement subsample. However, Panels D and E in Table 3 also show that the misclassification of fraudulent firms is high. Nevertheless, results from untabulated analyses applying the model to all available Chinese listed firms (2342 firms) indicate an impressive $81.17 \%$ correct prediction rate of no enforcement action for non-fraudulent firms and $57.37 \%$ correct prediction rate for fraudulent firms. These results suggest that the model can help to identify potential fraudulent firms.

\section{[Insert Table 3 Here]}

As reported in Table 4, to test the robustness of the results, a probit regression is performed by scaling all account balances by sales instead of total assets. The same significant relationships persist in many asset variables as with the previous analysis. The likelihood of 
fraud enforcement announcements is greater for firms that display higher other receivables, higher prepaid expenses and lower inventory balances. The previously identified pattern of asset account coefficients being double for firms with consecutive announcements relative to those with non-consecutive announcements is also confirmed. Similar relationships also persist on the liability side. The balance sheets of firms that are more likely to be exposed for fraud are characterised by higher employee benefits payable, long-term payables and deferred tax liabilities in the non-consecutive subsample, and lower deferred tax liabilities in the consecutive subsample. However, significant relationships for short-term loans and taxes payable are not observed in the sales-scaled regressions. Instead, the enforcement action for FFS is more likely when firms report lower share capital.

\section{[Insert Table 4 Here]}

The differences between the asset-based and sales-based regressions may be explained by the possibility of spurious relationships resulting from scaling by assets. On average, fraudulent firms have lower profitability and lower retained earnings balances, so the regression coefficients for asset-based ratios could be highly positive when the ratio denominators are lower, even when the associated account balance is not related to the status of fraud. This bias exists in asset-based ratios and can be significantly reduced by scaling by sales rather than assets. Nevertheless, sales are normally positively associated with total assets and the spurious relationship caused by total assets may indirectly, but to a lesser extent, also affect the results when scaling by sales.

Using the above reasoning, the earlier finding from the asset-based regressions that fraudulent firms have higher short-loans could be due to this spurious bias. Scaling the balance sheet values by assets has the advantage of enhancing the comparability of results with earlier studies that conclude that fraudulent firms have higher leverage (Chen et al., 2006; Firth et al., 2011). However, using sales-based regressions, higher leverage in fraudulent firms is found to concentrated in accounts payable, employee benefits payable, long-term payables and other non-current liabilities. Yet firms with consecutive enforcement actions have lower long-term debt and deferred tax liabilities. Given that different components of debt show different relationships, it is important for different components of debt to be analysed separately. 
The choice of scaling method also affects the findings with respect to retained earnings. While the asset-based regression results generally indicate positive coefficients for retained earnings, in the sales-based regression they are significantly negative. The latter indicates that fraudulent firms have lower retained earnings per unit value of average sales, which is consistent with the earlier univariate results. This analysis fails to reach a definitive conclusion with respect to retained earnings; hence this should be investigated further in future studies. While the use of residuals helps to eliminate problems of high correlations, it does not solve the identification problem completely.

The next analysis considers whether or not different types of fraud are associated with different balance sheet accounting ratios. As shown in Panel D of Table 1, there are many announcements of fraud cases that involve multiple fraud violations. Separate cross-sectional probit analyses are conducted for each of the six most common types of violations. Some of the similar but less common offences from types 7 to 9 are aggregated into one type (type789). The empirical results are detailed in Table 5. The correct prediction rates of an absence of fraud enforcement range from $69 \%$ for violations of delays in disclosure and false statements (types 3 and 4) to $88 \%$ for the illegal possession of funds (type6). Hence, the predictive power of the model improves when separate regressions are performed on separate subsamples of the most common types of violations.

\section{[Insert Table 5 Here]}

The likelihood of certain violations are found to be typically associated with specific balance sheet accounts. Firms that are more likely to falsify statements (type4) or delay disclosure (type5) tend to report lower cash and cash equivalents, whereas frauds involving illegal possession of funds (type6) have higher cash balances. Firms that are more likely to undertake fraudulent related-party transactions (type1) or false statements (type4) tend to have higher employee benefits payable and lower taxes payable balances. The exposure of violations using related-party transactions (type1) or external loan guarantees (type5) is associated with higher deferred tax liabilities. Furthermore, fraudulent firms that conceal significant contracts/events (type2) or make false statements (type4) report lower balances of other stockholders' equity. However, across the different types of violations tested, the most consistent predictor of fraud is other receivables; its coefficient is significantly positive in all seven types. This implies that other receivables may be commonly used in the conduct of many different types of fraud[1]. While some accounting ratios are commonly associated with 
the exposure of many different types of fraud, each violation type has its own special indicator(s)[2]. Hence, the results support the second hypothesis that there exists a relationship between the type of fraud violation and the specific accounts associated with that particular fraud. The tendencies for balance sheet accounts to be significantly high or low for each violation type are summarised in Table 6.

\section{[Insert Table 6 Here]}

Past studies present evidence that various characteristics of corporate governance are associated with quality of financial reporting (Beasley et al.; 1996; Chen et al., 2006; Firth et al., 2011; Liu and Lu, 2007). Corporate governance in China has distinct features that may or may not be effective in mitigating FFS. Accordingly, corporate governance and firm-level variables are next incorporated into the probit regression. Several corporate governance variables from past studies are included in the analysis: Govt (a dummy variable with a value of one if the government or a government-owned institution is the largest shareholder and zero otherwise), Tradable (proportion of shares owned by individual shareholders), Herfindahl (the concentration of shares held by the top ten shareholders, other than the controlling one), Top (shares held by the largest shareholder), INED (the percentage of independent directors on the board), Board (the number of directors on the board), Dual (a dummy variable that takes the value of one if the company's CEO is also the chairman of the board and zero otherwise), SBSIZE (the number of members on the supervisory board), SBMEET (the number of meetings of the supervisory board), and CPA (a dummy variable coded one if the auditor was one of the 10 biggest auditors by market share and zero otherwise). The firm-level variables are ST (a dummy variable coded one if the firm experienced special treatment before the announcement of fraud and zero otherwise), PT (a dummy variable coded one if the firm experienced particular transfer before the announcement of fraud and zero otherwise), and RET (annual stock return over risk-free rate). The results are reported in Table 7[3]. Panel A presents the results from a probit regression of all corporate governance variables on the propensity to conduct fraud. The significant variables from the Panel A regression, Board, Top, ST, PT and RET are then added as explanatory variables to the previous Table 3 probit regression of balance sheet account values on a corporate fraud indicator. The account variables are scaled by total assets (Panel B), and by total sales (Panel C). 
Chen et al. (2006) show that the presence of poor financial performance is associated with fraudulent behaviours. Also, board size may reduce the likelihood of fraud through better monitoring (Karamanou and Vafeas, 2005). As expected, the propensity to conduct fraud is negatively related a firm's board size (Board) and its annual stock returns (RET). The negative coefficient of Top suggests that large majority shareholdings can support an incentive alignment effect (Fan and Wong, 2002). For firm-level governance characteristics, the propensity to engage in financial fraud is positively affected by the designation of firms as special treatment (ST) or particular transfer (PT) status before the announcement year.

Most importantly, with respect to the main variables of interest in this study, the results in Panels B and C are broadly consistent with the prior results in Panels A, B and C of Tables 3 and 4. Specifically, other receivables, inventories, other current assets and long-term payables are consistently associated with a firms' propensity to commit fraud.

\section{Robustness tests}

The main results presented above explain the exposure of FFS using balance sheet account values over a three-year period centred on the announcement year of the fraud. To capture how account balances change before and after the disclosure of enforcement actions, annual regressions are next run with three subsamples in a one-year cross-section (year -1, year 0 and year +1 relative to the announcement year). The results are shown in Table 8 , and generally confirm the earlier significant relationships from Table 3. Additionally, a clear pattern is detected in the following significant variables: other receivables, prepaid expenses, other currents, short-term loans, deferred tax liabilities, and retained earnings. In these accounts, the coefficient values are highest in the year prior to the fraud announcement (year -1 ), and decline progressively in the announcement year (year 0 ) and year following (year +1 ). This is consistent with an interpretation that the public announcement of fraud may influence firms to moderate their fraudulent behaviours and/or engage in some remediation activities that are reflected in a progressive normalisation of the balance sheet accounts.

[Insert Table 8 Here] 
The previous model assumes that the cost of errors for fraud prediction (type I error) and nonfraud prediction (type II error) are the same. Furthermore, fraudulent firms are oversampled relative to their true proportion in all Chinese listed companies, so that the state-based sample contains more fraudulent firms than would a random sample. In addition, the probit model is a type of binary classification model, which uses the standard maximum likelihood procedure to estimate and this dichotomous-state model ignores the state-based sample procedures which can lead to biased coefficient estimates (Beneish, 1999b). For robustness, a weighted probit model is instead employed, and.untabulated results show that the prediction results remain unchanged.

\section{Conclusion}

This study employs a systematic approach to detect financial fraud in Chinese listed firm balance sheet statements. Each balance sheet account is hypothesized to be potentially used as a vehicle for FFS. The probability of balance sheet accounts being associated with various types of fraud is systematically investigated. In prior research, other receivables, inventories and total debt have been identified as determinants of fraud and those findings are confirmed in this study. However, this study produces evidence in both asset-scaled and sales-scaled regressions that high balances of prepaid expenses, other current assets, employee benefit payable and unusual balances of deferred tax liabilities are also commonly associated with fraud in Chinese listed company financial statements.

The values of the regression coefficients for balance sheet accounts that show a significant relationship to fraudulent statements are greatest prior to the year of the fraud violation announcement, become smaller in the announcement year and decline further the following year. This suggests that a public announcement to expose a fraud may have an impact on the firm committing the fraud, triggering a partial reversal effect visible through the financial statement accounts. The evidence presented that the coefficients of significant balance sheet accounts are greater for those firms experiencing consecutive announcements than for those with non-consecutive announcements is consistent with the interpretation that consecutive announcements are indicative of more serious fraud. 
This study also finds that many accounts are important indicators of different types of fraud; each type has its own important indicators. For example, when crimes involve concealing significant contracts or events, the accounts "other receivables", "prepaid expense" and "short-term loans" tend to be inflated. Generally the correct prediction rates of fraud are over $69 \%$ for most offences, which is well above the naïve correct prediction of 50\%. Importantly, the models may provide a helpful tool to detect FFS in all Chinese firms. The correct prediction rate of the absence of fraud in Chinese listed firms is an impressive $81 \%$. This study also challenges some earlier studies such as Chen et al. (2006), Jiang et al. (2010), and Stice (1999) that focus on a limited number of accounting ratios. There may be at least two methodological problems in such studies: the missing variables bias and spurious relationships. Results in this study suggest that the likelihood of fraud is detected through a variety of balance sheet accounts. Prior research to detect FFS has tended to investigate a limited number of accounts, suggesting the potential for missing variables and bias in the regression parameter estimates. Furthermore, the conventional practice of using asset-scaled explanatory variables to explain the propensity to engage in fraud may result in spurious relationships. For example, prior such studies find evidence of higher leverage for fraudulent firms (Chen et al., 2006; Spathis et al., 2002). Yet the results suggest that this could be a result of lower equity in fraudulent firms. By examining the components of debt separately, this study produces evidence of lower leverage in some liability accounts of fraudulent firms. Therefore, a thorough examination of all balance sheet account values and the adoption of two scaling methods (total assets and sales) are recommended in order to explore the relationship between balance sheet accounts and FFS.

This study finds that some ownership and governance characteristics of firms have an impact on the propensity to falsify financial statements. However, the only effective corporate governance mechanisms are board size and the percentage of shares held by the largest shareholder, which are negatively associated with FFS. Hence, the efficiency of corporate governance mechanisms in China remains a grave concern.

The research results are of considerable importance for both investors and regulators. For investors, the signals in balance sheet account information can assist them to control unsystematic investment risk. The prediction model may also be useful for the CSRC in the development of an early warning system for FFS, thereby assisting to improve the quality of financial reporting and deter misconduct by management. The CSRC can also use the 
common fraud types and malfeasant practices to promulgate detailed guidelines for auditors and directors to promote the integrity of financial reporting practices.

\section{References}

Agrawal, A. and Chadha, S. (2005). "Corporate Governance and Accounting Scandals*", Journal of law and Economics, Vol.48 No.2, pp. 371-406.

Aharony, J., Lee, C.-W. J. and Wong, T. J. (2000). "Financial packaging of IPO firms in China", Journal of Accounting Research, Vol. 38 No. 1, pp. 103-126.

Baucus, M. S. and Near, J. P. (1991). "Can illegal corporate behavior be predicted? An event history analysis", Academy of Management Journal, Vol.34 No.1, pp. 9-36.

Beasley, M. S. (1996). "An empirical analysis of the relation between the board of director composition and financial statement fraud", Accounting Review, pp. 443-465.

Beneish, M. D. (1999a). "Incentives and penalties related to earnings overstatements that violate GAAP”, The Accounting Review, Vol. 74 No. 4, pp. 425-457.

Beneish, M. D. (1999b). "The detection of earnings manipulation", Financial Analysts Journal, Vol. 55 No. 5, pp. 24-36.

Bonner, S. E., Palmrose, Z.-V. and Young, S. M. (1998). "Fraud type and auditor litigation: An analysis of SEC accounting and auditing enforcement releases", Accounting Review, pp. 503-532.

Chen, G., Firth, M., Gao, D. N. and Rui, O. M. (2006). "Ownership structure, corporate governance, and fraud: Evidence from China", Journal of Corporate Finance, Vol. 12 No. 3, pp. 424-448.

Chen, K. C. and Yuan, H. (2004). "Earnings management and capital resource allocation: Evidence from China's accounting-based regulation of rights issues", The Accounting Review, Vol. 79 No. 3, pp. 645-665.

Cheung, Y.-L., Jing, L., Lu, T., Rau, P. R. and Stouraitis, A. (2009). "Tunneling and propping up: An analysis of related party transactions by Chinese listed companies", Pacific-Basin Finance Journal, Vol. 17 No. 3, pp. 372-393.

Dechow, P. M., Ge, W., Larson, C. R. and Sloan, R. G. (2011). "Predicting Material Accounting Misstatements*", Contemporary accounting research, Vol. 28 No. 1, pp. 1782.

Fan, J. P., Rui, O. M. and Zhao, M. (2008). "Public governance and corporate finance: Evidence from corruption cases", Journal of Comparative Economics, Vol. 36 No. 3, pp. 343-364.

Fan, J. P. and Wong, T. J. (2002). "Corporate ownership structure and the informativeness of accounting earnings in East Asia", Journal of Accounting and Economics, Vol. 33 No. 3, pp. 401-425. 
Firth, M., Rui, O. M. and Wu, W. (2011). "Cooking the books: Recipes and costs of falsified financial statements in China", Journal of Corporate Finance, Vol. 17 No. 2, pp. 371390

Jia, C., Ding, S., Li, Y. and Wu, Z. (2009). "Fraud, enforcement action, and the role of corporate governance: Evidence from China", Journal of Business Ethics, Vol. 90 No. 4, pp. 561-576.

Jian, M. and Wong, T. J. (2010). "Propping through related party transactions", Review of Accounting Studies, Vol. 15 No. 1, pp. 70-105.

Jiang, G., Lee, C. and Yue, H. (2010). "Tunneling through intercorporate loans: The China experience", Journal of Financial Economics, Vol. 98 No. 1, pp. 1-20.

Karamanou, I. and Vafeas, N. (2005). "The association between corporate boards, audit committees, and management earnings forecasts: An empirical analysis", Journal of Accounting Research, Vol. 43 No. 3, pp. 453-486.

Liu, Q. (2006). "Corporate governance in China: Current practices, economic effects and institutional determinants”, CESifo Economic Studies, Vol. 52 No. 2, pp. 415-453.

Liu, Q. and Lu, Z. J. (2007). "Corporate governance and earnings management in the Chinese listed companies: A tunneling perspective", Journal of Corporate Finance, Vol. 13 No. 5, pp. 881-906.

Luo, X. and Hassan, M. (2009). "The role of top management networks for market knowledge creation and sharing in China", Journal of Business Research, Vol. 62 No. 10, pp. 1020-1026.

Peng, W. Q., Wei, K.-C. and Yang, Z. (2011). "Tunneling or propping: Evidence from connected transactions in China", Journal of Corporate Finance, Vol. 17 No. 2, pp. 306325 .

Simunic, D. A. (1980). "The pricing of audit services: Theory and evidence", Journal of Accounting Research, pp. 161-190.

Spathis, C., Doumpos, M. and Zopounidis, C. (2002). "Detecting falsified financial statements: a comparative study using multicriteria analysis and multivariate statistical techniques", European Accounting Review, Vol. 11 No. 3, pp. 509-535.

Stice, J. D. (1991). "Using financial and market information to identify pre-engagement factors associated with lawsuits against auditors", Accounting Review, pp. 516-533.

Szwajkowski, E. (1985). "Organizational illegality: Theoretical integration and illustrative application", Academy of Management Review, Vol.10 No.3, pp. 558-567. 


\section{Appendix 1: Examples of the violation types}

\section{Lengguang Industrial: Type 1 (Related party transactions)}

Shanghai Lengguang Industrial Co. Ltd., was penalized by the Shanghai Stock Exchange in 1999 for failing to disclose the exact amount of a major loan guarantee in a timely manner. In their 1998 annual report, Lengguang disclosed a total loan guarantee of 186.3 million RMB; however, this was upgraded to 3593.9 million RMB in their 1999 interim report.

\section{S*ST Yahua: Type 2 (Concealment of significant contracts or events)}

Hunan Yahua Holding Co. Ltd., was punished by the Shenzhen Stock Exchange and the CSRC in 2005 for failing to disclose aggregate stock market investment losses of 69.46 million RMB, amounting to $0.7 \%$ and $125 \%$ of 2000 and 2002 audited annual net profits, respectively. They also failed to disclose controlling by the company Hongyi.

\section{S*ST Jiazhi: Type 3 (Postponements/delays in disclosure)}

Jiamusijindi Paper Co. Ltd., was punished by the Shenzhen Stock Exchange in 2002 for failing to disclose the 2001 annual performance in a timely manner.

\section{ST Meiya: Type4 (False statement)}

Guangdong Meiya Group Co. Ltd.,was punished by the Shenzhen Stock Exchange in 2005 for a failure to timely, accurately and completely reveal the company's risk. Despite forecasting a positive profit in the third quarter 2004 report, ST Meiya reported a net loss of 203.36 million RMB in their 2004 annual report. 


\section{Table 1 Sample description of fraud}

This table presents the sample collection procedure (Panel A), the distributions across years (Panel B), industry (Panel C) and type of violation (Panel D) for the corporate fraud sample.

\begin{tabular}{lcc}
\hline Panel A: Sample exclusions & & \\
\hline & Firms & Cases \\
Number of announcements by the CSRC and two stock exchanges (1994- & $\mathbf{3 6 9}$ & $\mathbf{7 3 4}$ \\
$2011)$ & & \\
Reasons for deletions & 1 & 1 \\
$\quad$ B-share & 51 & 66 \\
$\quad$ No matching firms & 4 & 11 \\
$\quad$ Finance industry & 0 & 0 \\
$\quad$ Multiple announcement in the same year & 56 & 78 \\
Fraudulent firms deleted & $\mathbf{3 1 3}$ & $\mathbf{6 5 6}$ \\
Final sample size & 313 & \\
Number of matched control firms & 626 & \\
Total number of firms in the study & & \\
\hline
\end{tabular}

\begin{tabular}{|c|c|c|c|c|c|c|}
\hline \multicolumn{7}{|c|}{ Panel B: Distribution of fraud cases and fraud firms by year } \\
\hline \multirow[t]{2}{*}{ Years } & \multicolumn{2}{|c|}{ Fraud cases } & \multicolumn{2}{|c|}{ Fraud firms } & \multirow{2}{*}{$\begin{array}{c}\begin{array}{c}\text { Listed } \\
\text { firms }\end{array} \\
\text { Number }\end{array}$} & \multirow{2}{*}{$\begin{array}{c}\begin{array}{c}\text { Fraud firms/Listed } \\
\text { firms }\end{array} \\
\text { Percent }\end{array}$} \\
\hline & Number & Percent & Number & Percent & & \\
\hline 1994 & 2 & 0.30 & 2 & 0.37 & 291 & 0.69 \\
\hline 1995 & 0 & 0.00 & 0 & 0.00 & 323 & 0.00 \\
\hline 1996 & 4 & 0.61 & 4 & 0.74 & 530 & 0.75 \\
\hline 1997 & 10 & 1.52 & 10 & 1.85 & 745 & 1.34 \\
\hline 1998 & 5 & 0.76 & 5 & 0.92 & 851 & 0.59 \\
\hline 1999 & 13 & 1.98 & 13 & 2.40 & 949 & 1.37 \\
\hline 2000 & 14 & 2.13 & 14 & 2.58 & 1088 & 1.29 \\
\hline 2001 & 68 & 10.37 & 62 & 11.44 & 1160 & 5.34 \\
\hline 2002 & 55 & 8.38 & 47 & 8.67 & 1224 & 3.84 \\
\hline 2003 & 55 & 8.38 & 44 & 8.12 & 1287 & 3.42 \\
\hline 2004 & 61 & 9.30 & 53 & 9.78 & 1377 & 3.85 \\
\hline 2005 & 95 & 14.48 & 64 & 11.81 & 1381 & 4.63 \\
\hline 2006 & 92 & 14.02 & 66 & 12.18 & 1434 & 4.60 \\
\hline 2007 & 75 & 11.43 & 58 & 10.70 & 1550 & 3.74 \\
\hline 2008 & 37 & 5.64 & 33 & 6.09 & 1625 & 2.03 \\
\hline 2009 & 36 & 5.49 & 33 & 6.09 & 1718 & 1.92 \\
\hline 2010 & 15 & 2.29 & 15 & 2.77 & 2063 & 0.73 \\
\hline 2011 & 19 & 2.90 & 19 & 3.51 & 2342 & 0.81 \\
\hline total & 656 & 100 & 542 & 100 & & \\
\hline & & & & & Average & 2.27 \\
\hline
\end{tabular}




\begin{tabular}{lcccc}
\hline \multicolumn{5}{l}{ Panel C: Distribution of fraud cases and fraud firms by industry } \\
\hline Industries & Fraud cases & Fraud firms \\
\hline & Number & Percent & Number & Percent \\
Manufacturing & 333 & 50.76 & 173 & 55.27 \\
Real estate & 82 & 12.50 & 37 & 11.82 \\
Information technology & 62 & 9.45 & 20 & 6.39 \\
Wholesale and retail trade & 39 & 5.95 & 20 & 6.39 \\
Conglomerates & 35 & 5.34 & 22 & 7.03 \\
Farming, forestry, animal husbandry and fishery & 31 & 4.73 & 10 & 3.19 \\
Social services & 21 & 3.20 & 8 & 2.56 \\
Utilities & 16 & 2.44 & 9 & 2.88 \\
Construction & 13 & 1.98 & 5 & 1.60 \\
Transportation and warehousing & 11 & 1.68 & 4 & 1.28 \\
Mining & 10 & 1.52 & 4 & 1.28 \\
Communication and cultural industry & 3 & 0.46 & 1 & 0.32 \\
\hline Total & $\mathbf{6 5 6}$ & 100 & $\mathbf{3 1 3}$ & 100 \\
\hline
\end{tabular}

\begin{tabular}{lccc}
\hline \multicolumn{4}{l}{ Panel D: Distribution of fraud cases and fraud firms by violation types } \\
\hline Types & Instances of fraud & Percent & Type \# \\
\hline Related party transactions & 161 & 14.09 & 1 \\
Concealment of significant contracts or events & 145 & 12.69 & 2 \\
Postponement/delay in disclosure & 141 & 12.34 & 3 \\
False statement & 138 & 12.07 & 4 \\
External loan guarantees & 113 & 9.89 & 5 \\
Embezzlement by major shareholder & 77 & 6.74 & 6 \\
Fabrication of profits & 61 & 5.34 & 7 \\
Fictitious income or assets & 38 & 3.32 & 8 \\
Fictitious expenses/liabilities & 26 & 2.27 & 9 \\
False disclosure of the actual use of raised capital & 38 & 3.32 & 10 \\
Concealing lawsuits & 29 & 2.54 & 12 \\
Illegal share buy and sell & 21 & 1.84 & 13 \\
Mortgage of assets or/and equities & 6 & 0.52 & 14 \\
Fictitious supporting documents & 5 & 0.44 & 15 \\
Bribe & 1 & 0.09 & 16 \\
Illegal purchase of foreign exchange & 1 & 0.09 & 17 \\
Misstatement for IPO purposes & 1 & 0.09 & 18 \\
Others & 141 & 12.34 & 11 \\
\hline Total & 1143 & 100 & \\
\hline
\end{tabular}


Table 2 Descriptive statistics and mean comparison between fraud and matching firms (scaled by total assets)

Significances at the $1 \%, 5 \%$, and $10 \%$ are denoted by $* * *, * *$, and * respectively.

\begin{tabular}{|c|c|c|c|c|c|c|c|c|c|}
\hline & \multicolumn{3}{|c|}{ Panel A. Full Sample } & \multicolumn{3}{|c|}{ Panel B. Non-consecutive event } & \multicolumn{3}{|c|}{ Panel C. Consecutive event } \\
\hline Accounting Variables & Fraud & Matching & Diff & Fraud & Matching & Diff & Fraud & Matching & Diff \\
\hline Cash and cash equivalents & 0.123 & 0.156 & $-0.033 * * *$ & 0.129 & 0.155 & $-0.026 * * *$ & 0.100 & 0.161 & $-0.061 * * *$ \\
\hline Receivable & 0.056 & 0.102 & $-0.047 * * *$ & 0.058 & 0.104 & $-0.046 * * *$ & 0.047 & 0.096 & $-0.049 * * *$ \\
\hline Other receivables & 0.162 & 0.059 & $0.103 * * *$ & 0.153 & 0.064 & $0.089 * * *$ & 0.194 & 0.040 & $0.154 * * *$ \\
\hline Inventories & 0.135 & 0.182 & $-0.048 * * *$ & 0.140 & 0.180 & $-0.040 * * *$ & 0.114 & 0.191 & $-0.077 * * *$ \\
\hline Prepaid expenses & 0.038 & 0.038 & 0.000 & 0.040 & 0.038 & 0.002 & 0.033 & 0.038 & -0.005 \\
\hline Others currents & 0.011 & 0.006 & $0.005 * * *$ & 0.011 & 0.007 & $0.005 * * *$ & 0.012 & 0.004 & $0.008 * * *$ \\
\hline Fixed assets & 0.274 & 0.279 & -0.005 & 0.275 & 0.274 & 0.001 & 0.272 & 0.300 & $-0.028 *$ \\
\hline Intangible assets & 0.054 & 0.042 & $0.013 * * *$ & 0.056 & 0.044 & $0.012 * * *$ & 0.047 & 0.034 & $0.013 * * *$ \\
\hline Other non-current & 0.137 & 0.129 & 0.008 & 0.128 & 0.127 & 0.001 & 0.171 & 0.135 & $0.036 * * *$ \\
\hline Short-term loans & 0.269 & 0.177 & $0.092 * * *$ & 0.253 & 0.179 & $0.074 * * *$ & 0.328 & 0.168 & $0.160 * * *$ \\
\hline Notes payable & 0.023 & 0.027 & $-0.003^{*}$ & 0.024 & 0.026 & -0.002 & 0.022 & 0.030 & $-0.008 * *$ \\
\hline Accounts payable & 0.086 & 0.081 & $0.005 *$ & 0.088 & 0.082 & 0.006 & 0.079 & 0.075 & 0.004 \\
\hline Employee benefits payable & 0.009 & 0.008 & $0.001 * *$ & 0.009 & 0.008 & $0.001 *$ & 0.010 & 0.008 & $0.002 * *$ \\
\hline Taxes payable & 0.015 & 0.013 & 0.002 & 0.014 & 0.014 & 0.000 & 0.019 & 0.010 & $0.008 * * *$ \\
\hline Other short-term liabilities & 0.201 & 0.135 & $0.066^{* * *}$ & 0.186 & 0.141 & $0.046^{* * *}$ & 0.252 & 0.115 & $0.138 * * *$ \\
\hline Long-term debt & 0.044 & 0.045 & -0.001 & 0.048 & 0.046 & 0.002 & 0.028 & 0.040 & $-0.013 * *$ \\
\hline Long-term payable & 0.006 & 0.004 & $0.002 * *$ & 0.005 & 0.004 & $0.002 *$ & 0.006 & 0.004 & 0.003 \\
\hline Deferred tax liabilities & 0.001 & 0.001 & $0.000 *$ & 0.001 & 0.000 & $0.001 * * *$ & 0.000 & 0.001 & $-0.001 *$ \\
\hline Other non-current liabilities & 0.049 & 0.018 & $0.030 * * *$ & 0.045 & 0.022 & $0.023 * * *$ & 0.061 & 0.005 & $0.057 * * *$ \\
\hline Share capital & 0.311 & 0.251 & $0.059 * * *$ & 0.313 & 0.263 & $0.049 * * *$ & 0.303 & 0.207 & $0.096 * * *$ \\
\hline Capital reserves & 0.299 & 0.237 & $0.062 * * *$ & 0.292 & 0.244 & $0.048 * * *$ & 0.325 & 0.211 & $0.113 * * *$ \\
\hline Surplus reserves & 0.048 & 0.047 & 0.002 & 0.048 & 0.045 & 0.003 & 0.050 & 0.051 & -0.001 \\
\hline Retained earnings & -0.449 & -0.097 & $-0.352 * * *$ & -0.412 & -0.134 & $-0.278 * * *$ & -0.585 & 0.040 & $-0.624 * * *$ \\
\hline Other stockholder equity & 0.020 & 0.029 & $-0.010 * * *$ & 0.021 & 0.030 & $-0.009 * * *$ & 0.016 & 0.027 & $-0.012 * * *$ \\
\hline
\end{tabular}


Table 3 Probit regression results of balance sheet account values (scaled by total assets) on corporate fraud indicator

e1 and e2 are Fixed assets and Retained earnings residuals to control for multicollinearity. ${ }^{a}$ r1 (Correct 1) prediction is when a fraud firm is predicted as "Fraud $=1$ " and $\mathrm{r} 0$ (Correct 0 ) prediction is when a matching firm is correctly predicted as "Fraud $=0$ ". Significances at the $1 \%, 5 \%, 10 \%$ are denoted by $* * *$, **, and * respectively.

\begin{tabular}{|c|c|c|c|c|c|c|}
\hline & Panel A & Panel B & Panel C & Panel D & Panel E & Panel F \\
\hline & \multicolumn{3}{|c|}{ In-sample tests } & \multicolumn{3}{|c|}{ Out-of-sample prediction } \\
\hline & All firms & Non-consecutive & Consecutive & All firms & Non-consecutive & Consecutive \\
\hline Intercept & $-0.559 * * *$ & $-0.437 * * *$ & $-4.868 * * *$ & $-0.964 * * *$ & $-0.671 * * *$ & $-6.918 * * *$ \\
\hline Cash and cash equivalents & -0.270 & -0.135 & -0.415 & -0.225 & -0.161 & 1.153 \\
\hline Receivable & 0.033 & -0.349 & 1.860 & 0.469 & -0.138 & $2.873 * *$ \\
\hline Other receivables & $2.746 * * *$ & $2.273 * * *$ & $5.247 * * *$ & $2.985 * * *$ & $2.322 * * *$ & $7.337 * * *$ \\
\hline Inventories & $-0.997 * * *$ & $-0.939 * * *$ & $-2.143 * * *$ & $-0.934 * * *$ & $-1.172 * * *$ & $-1.666^{*}$ \\
\hline Prepaid expenses & $1.548 * * *$ & $1.756 * * *$ & $5.313 * * *$ & $2.126 * * *$ & $2.244 * * *$ & $7.887 * * *$ \\
\hline Others currents & $3.029 * * *$ & $2.192 * *$ & $6.184^{*}$ & $3.718 * * *$ & $2.757 * *$ & $9.723 * * *$ \\
\hline Fixed assets (e1) & $-1.097 *$ & -0.574 & $-21.485 * * *$ & 1.451 & $1.513^{*}$ & $-32.371 * * *$ \\
\hline Intangible assets & $1.537 * * *$ & $1.435 * * *$ & $3.598^{*}$ & $1.891 * * *$ & $1.697 * * *$ & 3.743 \\
\hline Other non-current & 0.246 & -0.068 & $2.068 * * *$ & $0.712 * *$ & 0.260 & $3.009 * * *$ \\
\hline Short-term loans & $0.742 * * *$ & $0.682 * * *$ & $4.878^{* * *}$ & $1.412 * * *$ & $1.337 * * *$ & $5.074 * * *$ \\
\hline Notes payable & -0.041 & -0.386 & $5.345 * * *$ & -0.059 & -0.404 & $7.544 * *$ \\
\hline Accounts payable & 0.351 & $0.794 *$ & $3.894 * *$ & $1.481 * * *$ & $1.843 * * *$ & $3.771 *$ \\
\hline Employee benefits payable & $11.004 * * *$ & $9.019 * * *$ & $35.559 * * *$ & $8.947 * *$ & 7.130 & $27.691 * *$ \\
\hline Taxes payable & $-2.266 * *$ & $-3.796 * * *$ & $14.460 * * *$ & 0.087 & -2.688 & $11.825^{*}$ \\
\hline Other short-term liabilities & 0.151 & -0.033 & $3.479 * * *$ & -0.354 & $-0.530 *$ & $7.238 * * *$ \\
\hline Long-term debt & 0.561 & $0.843^{*}$ & 2.359 & $0.929 *$ & $1.246^{* *}$ & 3.529 \\
\hline Long-term payable & $4.651 * * *$ & $4.037 * *$ & $19.963 * * *$ & $3.603 * *$ & 2.908 & $23.923 * * *$ \\
\hline Deferred tax liabilities & $17.369 * *$ & $29.442 * * *$ & $-47.850 *$ & -21.900 & -10.782 & -173.830 \\
\hline Other non-current liabilities & $-0.865 * * *$ & $-0.857 * *$ & $10.686 * * *$ & -0.247 & -0.564 & 5.865 \\
\hline Share capital & -0.184 & -0.086 & 0.433 & $-0.686^{* * *}$ & $-0.506^{* *}$ & 0.356 \\
\hline Capital reserves & 0.170 & 0.024 & $3.814 * * *$ & $0.616^{* * *}$ & $0.398 *$ & $6.294 * * *$ \\
\hline Surplus reserves & 0.345 & 1.059 & 1.523 & 0.307 & 1.093 & 2.557 \\
\hline Retained earnings (e2) & $0.206 * *$ & $0.173^{*}$ & $2.097 * *$ & $0.648 * * *$ & $0.406 * *$ & -2.978 \\
\hline Other stockholder equity & $-1.410 * *$ & $-1.870 * * *$ & $9.164 * * *$ & $-1.488 *$ & $-2.516 * * *$ & $9.274 * * *$ \\
\hline No. of Observations & 2468.00 & 1938.00 & 530.00 & 1816.00 & 1422.00 & 394.00 \\
\hline Log Likelihood & -1501.00 & -1211.00 & -181.26 & -1062.00 & -860.11 & -129.22 \\
\hline Correct prediction $1(\mathrm{r} 1)^{\mathrm{a}}$ & 0.57 & 0.57 & 0.81 & 0.43 & 0.37 & 0.72 \\
\hline Correct prediction $0(\mathrm{r} 0)^{\mathrm{a}}$ & 0.77 & 0.74 & 0.88 & 0.86 & 0.82 & 0.94 \\
\hline
\end{tabular}


Table 4 Probit regression results of balance sheet account values (scaled by sales) on corporate fraud indicator

${ }^{\mathrm{a}} \mathrm{r} 1$ (Correct 1) and $\mathrm{r} 0$ (Correct 0) prediction are defined in Table 3. Significances at the 1\%, 5\%, 10\% are denoted by ***,**, and * respectively.

\begin{tabular}{|c|c|c|c|}
\hline & \multicolumn{3}{|c|}{ Scaled by sales } \\
\hline & All firms & Non-consecutive & consecutive \\
\hline Intercept & $-0.160 * * *$ & $-0.111 * *$ & $-0.676 * * *$ \\
\hline Cash and cash equivalents & -0.044 & -0.028 & $-0.679 * * *$ \\
\hline Receivable & -0.067 & -0.119 & 0.545 \\
\hline Other receivables & $0.050^{* *}$ & 0.035 & $0.910 * * *$ \\
\hline Inventories & $-0.174 * * *$ & $-0.195 * * *$ & $-0.944 * * *$ \\
\hline Prepaid expenses & $0.417 * * *$ & $0.387 * *$ & $1.587 * *$ \\
\hline Others currents & $0.789 * * *$ & $0.625^{* *}$ & 0.002 \\
\hline Fixed assets & -0.026 & -0.004 & $-0.765 * * *$ \\
\hline Intangible assets & $0.376^{* * *}$ & $0.381 * * *$ & 0.247 \\
\hline Other non-current & -0.013 & $-0.066^{*}$ & $0.315^{* *}$ \\
\hline Short-term loans & 0.011 & 0.029 & 0.071 \\
\hline Notes payable & 0.18 & -0.052 & 1.292 \\
\hline Accounts payable & $0.411 * * *$ & $0.306^{* *}$ & $1.566^{* *}$ \\
\hline Employee benefits payable & $2.610 * * *$ & $1.905^{*}$ & $17.954 * * *$ \\
\hline Taxes payable & -0.28 & $-0.438^{*}$ & -0.636 \\
\hline Other short-term liabilities & -0.012 & -0.033 & -0.111 \\
\hline Long-term debt & 0.06 & $0.236 * *$ & $-1.093 * * *$ \\
\hline Long-term payable & $1.260 * * *$ & $0.956 *$ & $10.319 * * *$ \\
\hline Deferred tax liabilities & $8.401 * *$ & $17.351 * * *$ & $-41.858 * * *$ \\
\hline Other non-current liabilities & $0.255^{* *}$ & $0.181^{*}$ & $2.942 * * *$ \\
\hline Share capital & $-0.135 * * *$ & $-0.107 * * *$ & -0.182 \\
\hline Capital reserves & $0.058^{* *}$ & 0.048 & $0.605^{* * *}$ \\
\hline Surplus reserves & 0.014 & 0.152 & $-1.514 *$ \\
\hline Retained earnings & $-0.033 * *$ & -0.026 & $-0.732 * * *$ \\
\hline Other stockholder equity & -0.146 & $-0.360 *$ & $2.579 * * *$ \\
\hline No. of Observations & 2416 & 1914 & 502 \\
\hline Log Likelihood & -1562 & -1244 & -203.47 \\
\hline Correct prediction $1(\mathrm{r} 1)^{\mathrm{a}}$ & 0.45 & 0.45 & 0.73 \\
\hline Correct prediction $0(\mathrm{r} 0)^{\mathrm{a}}$ & 0.82 & 0.80 & 0.89 \\
\hline
\end{tabular}


Table 5 Probit regression results of different types of fraud violations and balance sheet accounts

Separate regressions are run for seven violation type subsamples. Descriptions of the types are in Table 1. Residuals (e1 and e2), ${ }^{\mathrm{a}} \mathrm{r}$ (Correct 1$)$ and $\mathrm{r} 0$ (Correct 0$)$ prediction are defined in Table 3 . Significances at the $1 \%, 5 \%, 10 \%$ are denoted by $* * *, * *$, and * respectively.

\begin{tabular}{|c|c|c|c|c|c|c|c|}
\hline & type1 & type 2 & type3 & type4 & type5 & type6 & type789 \\
\hline Intercept & $-1.121 * * *$ & 0.394 & 0.117 & -0.235 & $-3.089 * * *$ & $-3.199 * * *$ & $-1.075 * *$ \\
\hline Cash and cash equivalents & -0.114 & -0.567 & $2.201 * * *$ & $-1.405^{* *}$ & 0.997 & $2.300 * *$ & 0.214 \\
\hline Receivable & -1.361 & $-1.854 * *$ & -1.158 & -0.629 & -0.719 & 1.2 & -1.504 \\
\hline Other receivables & $6.559 * * *$ & $1.819 * * *$ & $4.245 * * *$ & $1.479 * *$ & $5.175 * * *$ & $6.627 * * *$ & $3.237 * * *$ \\
\hline Inven & $-2.173 * * *$ & $-4.037 * * *$ & $-2.448 * * *$ & -0.667 & -0.922 & $-3.718 * * *$ & 0.192 \\
\hline xpenses & $3.879 * * *$ & $2.520^{*}$ & 1.207 & 0.138 & $3.430^{* *}$ & 3.059 & $3.794 *$ \\
\hline Other & $7.884 * *$ & -2.571 & 3.113 & 1.566 & $12.536 * *$ & 2.003 & 2.786 \\
\hline Fixe & $-4.502 * *$ & $-4.448 * *$ & -0.902 & -2.401 & -2.661 & 3.341 & -0.22 \\
\hline Intan & 1.048 & -0.061 & -2.329 & $1.880 *$ & 1.078 & $3.620 * *$ & 1.445 \\
\hline Other non-current & -0.799 & 0.551 & 0.625 & -0.549 & 0.126 & $-3.511 * * *$ & -0.129 \\
\hline Short-term loans & $1.815 * * *$ & $1.436 * * *$ & 0.606 & $0.766 * *$ & $4.385 * * *$ & $4.678 * * *$ & $1.010^{* *}$ \\
\hline Note & 1.438 & -1.338 & -0.929 & 1.34 & 2.45 & 3.236 & -0.997 \\
\hline Ac & 1.795 & 0.669 & $4.343 * * *$ & -0.401 & $2.723 *$ & 1.959 & 1.421 \\
\hline able & $37.981 * * *$ & 6.695 & -11.389 & $19.903 * * *$ & 11.629 & -23.391 & 16.261 \\
\hline Taxes & $-14.365 * * *$ & $592 * * *$ & $-8.277 *$ & $-6.351 * *$ & 0.372 & $-9.040 *$ & $-7.319 * *$ \\
\hline Othe & -0.138 & 0.131 & -0.836 & 0.291 & 1.158 & $4.136 * * *$ & -0.505 \\
\hline rm debt & $2.179 * *$ & 0.456 & -0.969 & 1.309 & $3.607 * *$ & $3.445^{* *}$ & 1.939 \\
\hline Long-term payable & $8.427 *$ & -0.488 & 2.102 & 1.021 & $16.718^{*}$ & $18.438^{*}$ & 9.098 \\
\hline & $47.149 * * *$ & 7.361 & -8.787 & -0.086 & $60.919 * * *$ & $43.569 *$ & -13.984 \\
\hline Other & -1.373 & $-1.862 * *$ & $-3.265 * * *$ & -0.613 & $5.758^{* *}$ & 3.288 & -1.589 \\
\hline Shar & 0.438 & 0.44 & 0.867 & -0.126 & 0.49 & $2.117 * *$ & $1.547 * * *$ \\
\hline & -0.199 & 0.086 & 0.031 & 0.31 & $1.544 *$ & $1.782 * *$ & 0.474 \\
\hline & -0.009 & -3.343 & -1.373 & 1.457 & -3.698 & $6.930^{*}$ & $-8.341 * * *$ \\
\hline Reta & $0.542^{* *}$ & 0.199 & $2.106 * * *$ & 0.133 & 1.792 & -0.965 & -0.129 \\
\hline Other stockholder equity & -0.866 & $-4.568 * * *$ & 2.367 & $-6.780 * * *$ & 0.137 & -1.882 & 3.188 \\
\hline No. o & 564 & 510 & 354 & 498 & 342 & 306 & 276 \\
\hline Log Likelihood & -247.63 & -272.53 & -191.49 & -292.2 & -132.43 & -110.08 & -157.93 \\
\hline Correct predictic & 0.74 & 0.71 & 0.69 & 0.69 & 0.77 & 0.83 & 0.70 \\
\hline Correct prediction $0(\mathrm{r} 0)^{\mathrm{a}}$ & 0.85 & 0.76 & 0.74 & 0.75 & 0.83 & 0.88 & 0.76 \\
\hline
\end{tabular}


Table 6 Balance sheet accounts associated with each type of fraud violation

The tendencies for balance sheet accounts to be significantly high or low for each violation type are shown below. Descriptions of the types are in Table 1 . Residuals (e1 and e2), ${ }^{a} \mathrm{r} 1$ (Correct 1 ) and $\mathrm{r} 0$ (Correct 0$)$ prediction are defined in Table 3.

\begin{tabular}{|c|c|c|c|c|c|c|c|}
\hline & Type1 & Type2 & Type3 & Type4 & Type5 & Type 6 & Type 789 \\
\hline Cash and cash equivalents & & & Low & Low & & High & \\
\hline Receivable & & Low & & & & & \\
\hline Other receivable & High & High & High & High & High & High & High \\
\hline Inventories & Low & Low & Low & & & Low & \\
\hline Prepaid expenses & High & High & & & High & & High \\
\hline Others currents & High & & & & High & & \\
\hline Fixed assets (e1) & Low & Low & & & & & \\
\hline Intangible assets & & & & High & & High & \\
\hline Other non-current & & & & & & Low & \\
\hline Short-term loans & High & High & & High & High & High & High \\
\hline Notes payable & & & & & & & \\
\hline Accounts payable & & & High & & High & & \\
\hline Employee benefits payable & High & & & High & & & \\
\hline Taxes payable & Low & Low & Low & Low & & Low & Low \\
\hline Other short-term liabilities & & & & & & High & \\
\hline Long-term debt & High & & & & High & High & \\
\hline Long-term payable & High & & & & High & High & \\
\hline Deferred tax liabilities & High & & & & High & High & \\
\hline Other non-current liabilities & & Low & Low & & High & & \\
\hline Share capital & & & & & & High & High \\
\hline Capital reserves & & & & & High & High & \\
\hline Surplus reserves & & & & & & High & Low \\
\hline Retained earnings (e2) & High & & High & & & & \\
\hline Other stockholder equity & & Low & & Low & & & \\
\hline
\end{tabular}


Table 7 Probit regression results of balance sheet accounts, corporate ownership, board structure, and firm specific information on corporate fraud

Accounting variables are defined as the account to total assets in Panel B and deflated by sales in Panel C. e1 and e2 are Fixed assets and Retained earnings residuals to control for multicollinearity in Panel B. Significances at the $1 \%, 5 \%, 10 \%$ are denoted by $* * *, * *$, and $*$ respectively.

\begin{tabular}{|c|c|c|c|c|}
\hline & Panel A & & Panel B & Panel C \\
\hline & & & Asset- based & Sales- based \\
\hline \multirow[t]{16}{*}{ Intercept } & \multirow[t]{16}{*}{0.889} & Intercept & -0.140 & $0.429 *$ \\
\hline & & Cash and cash equivalents & -0.026 & -0.084 \\
\hline & & Receivable & $1.385 * * *$ & $0.240^{*}$ \\
\hline & & Other receivables & $3.892 * * *$ & $0.246^{* * *}$ \\
\hline & & Inventories & $-0.878 * *$ & -0.104 \\
\hline & & Prepaid expenses & 1.287 & 0.302 \\
\hline & & Others currents & $5.961 * * *$ & $2.062^{* * *}$ \\
\hline & & Fixed assets (e1) & 0.436 & -0.002 \\
\hline & & Intangible assets & -0.038 & -0.039 \\
\hline & & Other non-current & $0.653 *$ & $0.115^{* *}$ \\
\hline & & Short-term loans & $0.853 * * *$ & 0.033 \\
\hline & & Notes payable & 1.105 & 0.546 \\
\hline & & Accounts payable & $1.139 *$ & 0.367 \\
\hline & & Employee benefits payable & 5.468 & 1.020 \\
\hline & & Taxes payable & -2.284 & -0.842 \\
\hline & & Other short-term liabilities & -0.453 & $-0.154 * * *$ \\
\hline Tradable & -0.389 & Long-term debt & $2.178 * * *$ & $0.291 * *$ \\
\hline Herfindahl & -2.256 & Long-term payable & $4.146^{*}$ & $1.261 *$ \\
\hline Dual & -0.055 & Deferred tax liabilities & 8.341 & $11.606 * *$ \\
\hline Govt & -0.088 & Other non-current liabilities & 0.412 & 0.278 \\
\hline SBSIZE & 0.011 & Share capital & $-0.969 * * *$ & $-0.309 * * *$ \\
\hline INDE & -0.316 & Capital reserves & 0.262 & 0.033 \\
\hline MEET & 0.012 & Surplus reserves & 0.391 & $0.488^{*}$ \\
\hline SBMEET & 0.017 & Retained earnings (e2) & 0.007 & $-0.072 *$ \\
\hline CPAs & 0.004 & Other stockholder equity & -1.545 & -0.070 \\
\hline Board & $-0.041 * *$ & Board & -0.033 & $-0.037 *$ \\
\hline Top & $-1.402 * * *$ & Top & $-1.199 * * *$ & $-1.256 * * *$ \\
\hline ST & $1.095 * * *$ & ST & $1.126^{* * *}$ & $1.165^{* * *}$ \\
\hline PT & $1.767 * * *$ & PT & $2.423 * * *$ & $2.627 * * *$ \\
\hline RET & $-0.084 * * *$ & RET & -0.002 & -0.071 \\
\hline No. of Observations & 1204 & No. of Observations & 1204 & 1204 \\
\hline Log Likelihood & -742.09 & Log Likelihood & -644.58 & -687.24 \\
\hline
\end{tabular}


Table 8 Probit regression results of balance sheet account values on corporate fraud indicator - Robustness check

This table presents annual regressions with three subsamples in a one-year cross-section, with Year 0 representing the fraud announcement year.

Residuals (e1 and e2), ${ }^{\mathrm{a}} \mathrm{r}$ (Correct 1) and r0 (Correct 0) prediction are defined in Table 3. Significances at the $1 \%, 5 \%, 10 \%$ are denoted by $* * *, * *$, and $*$ respectively.

\begin{tabular}{l|rrr}
\hline & \multicolumn{3}{|c}{ Event year } \\
\hline & Year -1 & Year 0 & Year +1 \\
\hline Intercept & $-0.567^{*}$ & $-0.487^{*}$ & $-0.650^{* * *}$ \\
Cash and cash equivalents & -0.083 & -0.68 & 0.096 \\
Receivable & 0.189 & -0.455 & -0.097 \\
Other receivables & $3.683^{* * *}$ & $2.905^{* * *}$ & $2.002^{* * *}$ \\
Inventories & $-1.282^{* * *}$ & $-1.530^{* * *}$ & -0.437 \\
Prepaid expenses & $2.442^{* *}$ & 1.609 & 0.468 \\
Others currents & 3.395 & $3.360^{* *}$ & 2.596 \\
Fixed assets (e1) & -1.957 & $-2.316^{*}$ & -0.059 \\
Intangible assets & 0.125 & 1.339 & $2.268 * * *$ \\
Other non-current & -0.095 & 0.124 & 0.588 \\
\hline Short-term loans & $1.332^{* * *}$ & $1.036 * * *$ & 0.421 \\
Notes payable & 0.401 & -0.026 & -0.486 \\
Accounts payable & 0.467 & 0.083 & 0.861 \\
Employee benefits payable & 7.854 & $17.182^{* * *}$ & $10.974 * *$ \\
Taxes payable & -0.411 & -1.712 & -1.716 \\
Other short-term liabilities & -0.242 & 0.535 & 0.005 \\
Long-term debt & 0.556 & -0.215 & 0.939 \\
Long-term payable & 1.197 & $6.375^{* *}$ & $5.028 *$ \\
Deferred tax liabilities & $36.666^{*}$ & 18.124 & 8.634 \\
Other non-current liabilities & -0.056 & -0.981 & $-1.211^{* *}$ \\
Share capital & $-0.682^{*}$ & -0.42 & 0.194 \\
Capital reserves & -0.132 & 0.249 & 0.215 \\
Surplus reserves & 1.688 & 0.432 & -0.647 \\
Retained earnings (e2) & $1.294 * * *$ & $0.615 * *$ & 0.022 \\
Other stockholder equity & -0.118 & -1.363 & $-1.911 *$ \\
\hline No. of Observations & 770 & 928 & 770 \\
Log Likelihood & -458.62 & -525.50 & -485.30 \\
\hline Correct prediction 1 (r1) $)^{\mathrm{a}}$ & 0.61 & 0.61 & 0.56 \\
Correct prediction 0 (r0) & 0.75 & 0.80 & 0.77 \\
\hline & & & \\
& & & \\
& & &
\end{tabular}




\section{Notes}

${ }^{1}$ This finding is confirmed in robustness tests that scale the accounts using sales instead of total assets.

${ }^{2}$ The relationship between types of fraud and balance sheet accounting ratios is also examined by employing clean data. Clean data means only firms with a single type of fraudulent activity are included. Similar results around found as reported previously.

${ }^{3}$ The VIF is computed for each variable; no VIF is greater than 3. 


\title{
Detecting Fraud in Chinese Listed Company Balance Sheets
}

\author{
Wei, Y
}

2016-04-01

http://hdl.handle.net/10179/8746

22/04/2023 - Downloaded from MASSEY RESEARCH ONLINE 